\title{
Decreased thyroid follicle size in dwarf mice may suggest the role of growth hormone signaling in thyroid growth regulation
}

\author{
Adam Gesing ${ }^{1,2^{*}}$, Andrzej Bartke ${ }^{2}$, Michal M Masternak ${ }^{3,4}$, Andrzej Lewiński,
}

and Małgorzata Karbownik-Lewińska ${ }^{1,6}$

\begin{abstract}
Background: Altered somatotrophic signaling is among the most important potential mechanisms of extended longevity. Ames dwarf (df/df) mice are homozygous for mutation at the Prop-1 gene, leading to a lack of growth hormone $(\mathrm{GH})$, prolactin and thyroid stimulating hormone (TSH). Mice homozygous for targeted disruption of the growth hormone receptor/growth hormone binding protein gene are known as $\mathrm{GH}$ receptor knockout (GHRKO) mice or "Laron dwarf". Both, df/df and GHRKO mice, are characterized by reduced body size, low plasma insulin and insulin-like growth factor-I (IGF-I), remarkably extended longevity, and severe (in df/df mice) or mild (in GHRKO mice) thyroid hypofunction. Recently, by crossing df/df and GHRKO mice, double-mutant Ames dwarf/GHRKO ( $d f / K O)$ mice were created. Interestingly, these mice are smaller than Ames dwarfs or GHRKOs, and also have reduced insulin and IGF-I levels. The aim of the study was to investigate if and to what extent certain thyroid morphological parameters, such as inner follicular surface area, inner follicular perimeter, as well as the follicular epithelium thickness are changed in the examined dwarf mice.

Methods: This quantification was performed in thyroids collected from df/df, GHRKO and df/KO female mice, at approximately 5-6 months of age. We used a computerized plotting programme that combines a live microscopic image of the slide with an operator-generated overlay.

Results: Inner follicular surface area and inner follicular perimeter were decreased in all examined kinds of dwarf mice as compared to normal animals. Furthermore, decreases in these two parameters were more pronounced in $\mathrm{df} / \mathrm{df}$ and $\mathrm{df} / \mathrm{KO}$ than in GHRKO mice. Concerning the follicular epithelium thickness, only a tendency towards decrease of this parameter was found in all three kinds of dwarf mice.

Conclusions: Parameters characterizing thyroid follicle size are decreased in all three examined models of dwarf mice, which may explain decreased thyroid hormone levels in both basal mutants (Ames dwarfs and GHRKOs). $\mathrm{df} / \mathrm{df}$ mutation seems to predominate over GHRKO genetic intervention concerning their effects on thyroid growth. Beside TSH, also GH signaling seems to constitute a crucial element in the regulation of thyroid growth and, possibly, function.
\end{abstract}

Keywords: Ames dwarf mice, GHRKO mice, Thyroid follicle, Inner follicular surface area, Inner follicular perimeter, Follicular epithelium thickness

\footnotetext{
* Correspondence: adges7@wp.pl

${ }^{1}$ Department of Oncological Endocrinology, Chair of Endocrinology and

Metabolic Diseases, Medical University of Lodz, Lodz, Poland

${ }^{2}$ Department of Internal Medicine, Geriatrics Research, Southern Illinois

University School of Medicine, Springfield IL, USA

Full list of author information is available at the end of the article
} 


\section{Background}

The thyroid gland plays a crucial role, through thyroid hormones $(\mathrm{TH})$ synthesis, in the regulation of various physiological processes, including development of the central nervous system, skeletal growth or heat production. The synthesis of $\mathrm{TH}$ is regulated by hypothalamuspituitary-thyroid axis in the negative feedback loop. Also concerning the regulation of thyroid growth processes, the hypothalamus-pituitary-thyroid axis constitutes the main mechanism, with thyroid stimulating hormone (TSH) being the strongest stimulatory factor for thyroid hyperplasia and proliferation. However, the role of other factors, such as, for example, insulin-like growth factor-I (IGF-I) or epidermal growth factor (EGF), in thyroid development, growth and function, is considered and, partially, documented [1-4]. The possible strong contribution of factors other than "classical" to the regulation of thyroid growth and function is further supported by the following observation. It has been recently found that iodine-deficient diet does not induce thyroid enlargement, whereas decreasing thyroxine secretion in Slc26a4-null mutant mice, being an experimental model for Pendred syndrome [5].

Concerning external factors, iodine deficiency is proven to be the most common cause of thyroid enlargement, leading to goiter formation [1]. Importantly, a high prevalence of goiter is observed in patients with acromegaly [characterized by increased growth hormone (GH) synthesis and elevated IGF-I level] [6]. Furthermore, the increased prevalence of thyroid cancer in acromegalic patients is observed $[7,8]$. In turn, the transgenic mice over-expressing $\mathrm{GH}$, which may constitute an experimental model of acromegaly, are characterized by increased adult body mass and drastically shortened lifespan [9].

In agreement with the above, experimental evidence suggests that reduced $\mathrm{GH}$ signaling may contribute to lifespan extension. Therefore, several types of laboratory animals with disruption of somatotrophic axis are used in aging research. The animals with altered somatotrophic signaling are, among others, Ames dwarf (df/df) mice. These rodents are homozygous for a spontaneous recessive mutation at the transcription factor Prop-1, leading to a lack of $\mathrm{GH}$ (with undetectable plasma level of IGF-I), prolactin (Prl) and TSH [10]. The absence of $\mathrm{GH}, \mathrm{Prl}$ and TSH is a consequence of hypofunctional development of the anterior pituitary and a failure of differentiation of lactotrophs, somatotrophs and thyrotrophs [10]. Interestingly, these dwarf mice live much longer than their normal siblings [11] and are characterized by delayed aging [12], small body size and delayed puberty [13]. Moreover, Ames dwarfs have decreased plasma glucose and insulin levels [13], enhanced insulin sensitivity [14], reduced body core temperature [15], enhanced mitochondrial function [16] and importantly, they are severely hypothyroid [13].

Another experimental model characterized by prolonged lifespan results from genetic intervention which relies on the targeted disruption of the $\mathrm{GH}$ receptor/GH binding protein gene (Ghr/bp gene) [17]. Mice homozygous for this mutation are known as $\mathrm{GH}$ receptor/GH binding protein knockout (GHRKO; Ghr/bp -l-) mice or "Laron dwarf" [17]. These GH-resistant mice also live longer than their normal siblings and are characterized by reduced mass and body size, undetectable level of GH receptors, high level of serum $\mathrm{GH}$, greatly reduced plasma levels of insulin and IGF-I, enhanced insulin sensitivity, reduced oxidative damage and improved oxidative stress resistance [13,17-26]. Furthermore, GHRKO mice have lower incidence and delayed onset of fatal neoplastic diseases [27]. The mice with disrupted GH receptor are also characterized by decreased levels of pro-apoptotic factors [28-30] and increased levels of key regulators of mitochondrial biogenesis [31,32]. Importantly, GHRKO mice may have decreased thyroid hormone levels [33], however the results are not consistent [33,34]. Presumably, the differences in levels of thyroid hormones in GHRKO mice may be gender- and age-dependent $[33,34]$. Similar observations, showing gender-specific changes in thyroid hormones levels in humans during aging, were reported by Suzuki et al. [35].

Interestingly, by crossing $\mathrm{df} / \mathrm{df}$ and GHRKO mice, double-mutant Ames dwarf/GHRKO (df/KO) mice have been recently created. These mice lacking circulating $\mathrm{GH}$ and $\mathrm{GH}$ receptor are smaller than Ames dwarfs or GHRKOs, and also have reduced insulin and IGF-I levels [36].

The aim of the study was to investigate if and to what extent certain thyroid morphological parameters, such as inner follicular surface area, inner follicular perimeter, as well as the follicular epithelium thickness are changed in the examined dwarf mice.

\section{Methods}

\section{Animals}

Normal mice $(\mathrm{N} ; \mathrm{n}=5)$, Ames dwarf mice $(\mathrm{df} / \mathrm{df} ; \mathrm{n}=5)$, growth hormone receptor knockout mice, derived from animals kindly provided by Dr. J.J. Kopchick (Ohio University, Athens, OH, USA) (GHRKO; $\mathrm{n}=7$ ) and doublemutant Ames dwarf/GHRKO mice $(\mathrm{df} / \mathrm{KO} ; \mathrm{n}=7$ ) (all females) were bred and maintained under temperatureand light-controlled conditions $\left(22 \pm 2^{\circ} \mathrm{C}, 12 \mathrm{hr}\right.$ light/ $12 \mathrm{hr}$ dark cycle). At 5-6 months of age, the animals were anesthetized and euthanized by decapitation. After decapitation, thyroid lobes were collected and fixed in $10 \%$ formalin for 6 hours, and, next, in $70^{\circ}$ alcohol. Then, the procedure of embedding of thyroid lobes in paraffin wax (using $95^{\circ}$ alcohol, aniline, carboxylene, xylene and, 
finally, paraffin) was performed. Next, the paraffin sections ( $4 \mu \mathrm{m}$ thick), after deparaffinating, were stained with hematoxylin and eosin.

\section{Assessment of thyroid morphological parameters}

In order to evaluate the inner follicular surface area, inner follicular perimeter and follicular epithelium thickness, a computerized microscopy analysis system (Neurolucida, MicroBright Field Inc, Colchester, VT, USA) was used. This programme combines a live microscopic image of the slide with an operator-generated overlay.

\section{Statistical analysis}

The data were statistically analysed, using Student's unpaired $t$ test or the one-way analysis of variance (ANOVA), followed by Student-Newman-Keuls' test. Statistical significance was determined at the level of $p<0.05$. The results, obtained from the right and left lobes, are jointly depicted in the figures and expressed as means \pm SEM. All statistical calculations were conducted using SPSS version 17.0 (SPSS, Chicago, IL) with $\alpha=0.05$. All graphs were made using Prism 4.02 (GraphPad Software, San Diego, CA).

\section{Results}

Inner follicular surface area was decreased in Ames dwarf (df/df), GHRKO and double-mutant Ames dwarf/ GHRKO mice (df/KO) as compared to normal animals $(\mathrm{p}<0.001$ all) (Figure 1). Moreover, this morphological parameter was also decreased in $\mathrm{df} / \mathrm{df}$ and $\mathrm{df} / \mathrm{KO}$ mice in comparison with GHRKO dwarfs $(\mathrm{p}=0.034, \mathrm{p}=0.04$, respectively) (Figure 1). No changes in inner follicular surface area between $\mathrm{df} / \mathrm{df}$ and $\mathrm{df} / \mathrm{KO}$ mice were observed (Figure 1). Similarly to inner follicular surface area, also inner follicular perimeter was decreased in $\mathrm{df} /$ df, GHRKO and $\mathrm{df} / \mathrm{KO}$ mice as compared to normal

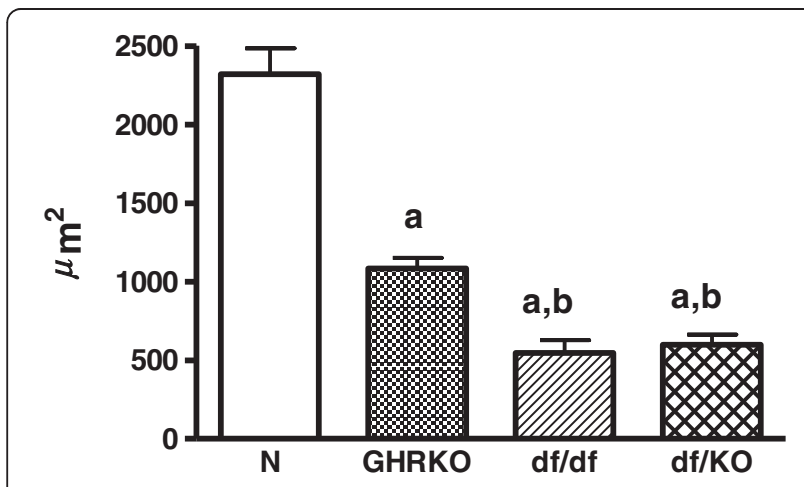

Figure 1 Inner follicular surface area. Inner follicular surface area in normal $(\mathrm{N})$, growth hormone receptor/binding protein knockout (GHRKO), Ames dwarf (df/df) and double-mutant Ames dwarf/GHRKO (df/KO) mice. Values are means \pm SEM. $a-p<0.001$ vs. normal mice; $b-p<0.05$ vs. GHRKO mice. animals $(\mathrm{p}<0.001$ all $)$ (Figure 2). The inner follicular perimeter was also decreased in $\mathrm{df} / \mathrm{df}$ and $\mathrm{df} / \mathrm{KO}$ mice in comparison with GHRKO animals $(\mathrm{p}=0.039, \mathrm{p}=0.028$, respectively) (Figure 2). Furthermore, this parameter did not differ between $\mathrm{df} / \mathrm{df}$ and $\mathrm{df} / \mathrm{KO}$ mice (Figure 2). Concerning the follicular epithelium thickness, only a tendency towards decrease of this parameter in all kinds of the examined dwarf mice was found (Figure 3).

\section{Discussion}

We have expectedly observed in our study that the inner follicular surface area and the inner follicular perimeter were decreased in all examined kinds of dwarf mice. At least two causes of such results can be considered. First, the decrease of these parameters may be a direct consequence of smaller sizes and masses of Ames dwarf (df/ $\mathrm{df}), \mathrm{GHRKO}$ and $\mathrm{df} / \mathrm{KO}$ mice as compared to normal animals. In accordance with our observation, Bartke [37] reported previously that the thyroid glands of Ames dwarfs and Snell mice (another kind of dwarf mice, characterized by a mutation at the transcription factor Pit-1 [38]) were greatly reduced in size, the follicles were small, and in the center of each lobe a considerable amount of the tissue was not organized into follicles. Similarly, Cordier et al. [39] demonstrated reduced follicular parameters (e.g. follicular surface and volume) in Snell mice as compared to normal mice. According to such an explanation, even lower values of measured parameters should be observed in double mutants, i.e. $\mathrm{df} / \mathrm{KO}$, as they are characterized by smaller body mass and size when compared to df/df or GHRKO mice [36]. However, both, the inner follicular surface area and the inner follicular perimeter in double mutants $\mathrm{df} / \mathrm{KO}$ were the same as in case of $\mathrm{df} / \mathrm{df}$ mice. This means that the additional experimental intervention, namely GHRKO, did not add anything concerning these parameters. Therefore, the lack of

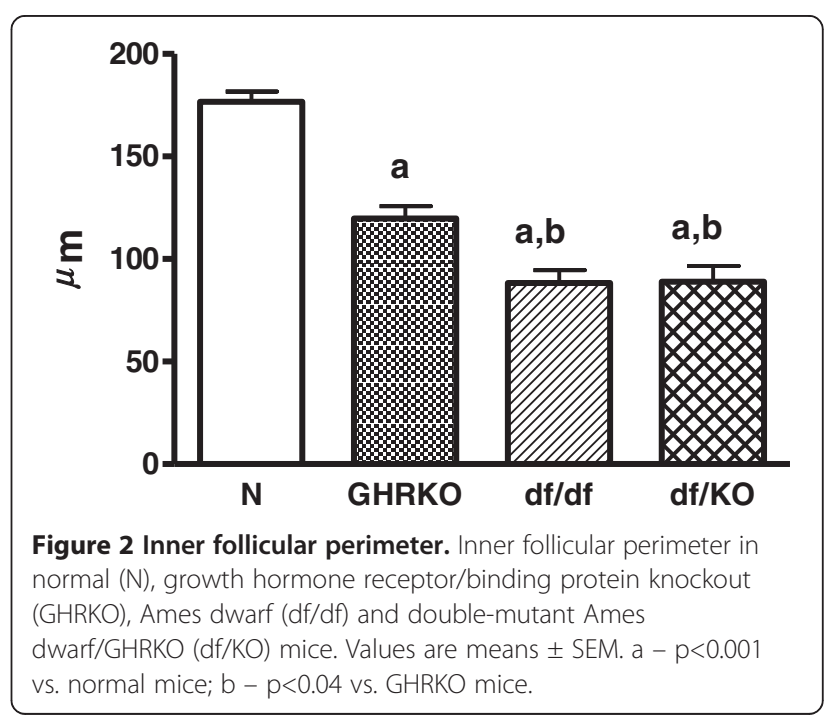




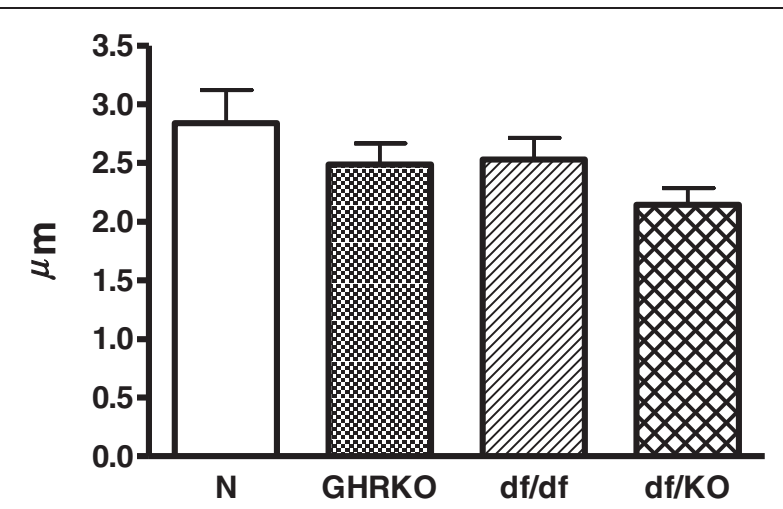

Figure 3 Follicular epithelium thickness. Follicular epithelium thickness in normal (N), growth hormone receptor/binding protein knockout (GHRKO), Ames dwarf (df/df) and double-mutant Ames dwarf/GHRKO (df/KO) mice. Values are means \pm SEM.

differences in the examined thyroid morphological parameters between $\mathrm{df} / \mathrm{KO}$ and $\mathrm{df} / \mathrm{df}$ mice suggests that some additional factors could exist, being responsible for such result, and presumably it may be linked to thyroid secreting function. Thus, the second cause may relate to certain factors which decrease thyroid function much stronger in $\mathrm{df} / \mathrm{df}$ mice [13] than in GHRKO animals [33]. Thus, on the basis of our results we can suggest that df/ df mutation predominates over GHRKO genetic intervention concerning their effects on thyroid growth and, possibly, function. However, further analysis of thyroid function in $\mathrm{df} / \mathrm{KO}$ mice is needed.

It is clear that the interruption of somatotrophic axis (at different levels) is responsible for the smaller body mass, smaller body size and smaller size of different organs, thyroid included, in dwarf mice. In this context, it is worth stressing that IGF-I acts also locally in the thyroid gland, e.g. via enzymes involved in DNA synthesis [40]. Furthermore, IGF-I may contribute to thyroid cancers development [41]. Therefore, the somatotrophic signaling can also be reduced in this endocrine gland in dwarf mice, what may, presumably, lead to the decrease of the examined thyroid morphological parameters.

Furthermore, decreased inner follicular surface area and inner follicular perimeter in dwarf mice may suggest smaller amount of colloid in the thyroid gland. It is known that decreased colloid content is observed in hyperthyroidism. In contrast, $\mathrm{df} / \mathrm{df}$ and GHRKO mice are characterized, as was reported above, by severe (in $\mathrm{df} / \mathrm{df}$ mice) or mild (in GHRKO mice) thyroid hypofunction. However, one should conclude that results from the present study can not be directly extrapolated into the studies in humans. Even contradictory results have been obtained between experimental studies in humans. For example, whereas decreased oxidative stress was found in dwarf mice [13], huge oxidative damage to membrane lipids was reported in GH-deficient patients
$[42,43]$, the phenomenon which was partially reversed by $\mathrm{GH}$ replacement [43].

Interestingly, both GH and IGF-I increased the ironinduced lipid peroxidation (LPO) in porcine thyroid homogenates [44]. On the other hand, GH and IGF-I may prevent the iron-induced oxidative damage in other tissues [45]. These results suggest that somatotrophic axis may reveal either pro-oxidative or anti-oxidative action, depending on the current redox status. This, in turn, may contribute to the regulation of thyroid growth and function [46].

The results of the present study are important not only in the context of longevity. There is a strong relationship between thyroid function, GH-IGF-I axis and bone linear growth in animals and humans. It is well known that thyroid hormones are indispensable for bone linear growth. Additionally, untreated hypothyroidism unfavourably affects the results of replacement therapy in GH-deficient patients and also it disturbes the results during diagnosis $[47,48]$. Thus, further studies, morphological evaluation included, on the thyroid function in subjects with disturbed GH-IGF-I axis would be of great importance.

Taking into account all above observations, one should hypothesize that GH signaling may contribute to thyroid growth and/or function, and that thyroid function (and/or morphological development) may be somehow affected by somatotrophic axis, although various other factors contributing to the development of thyroid gland are also known.

\section{Conclusions}

Parameters characterizing thyroid follicle size are decreased in all examined kinds of dwarf mice, which may explain decreased thyroid hormone levels in both basal mutants (Ames df/df dwarfs and GHRKOs). df/df mutation seems to predominate over GHRKO genetic intervention concerning their effects on thyroid growth. Beside TSH, also GH signaling seems to constitute a crucial element in thyroid growth and, possibly, function.

\section{Competing interests}

The authors declare that they have no competing interests.

\section{Authors' contributions}

AG designed and performed the experiment, assessment of thyroid morphological parameters, data analyses and interpretation and wrote the manuscript. MKL supervised preparation of the manuscript and was involved in the interpretation of the results. MMM and $A B$ contributed to the experimental design. MMM, $A L$ and $A B$ were involved in the interpretation of the results and review of the manuscript. All authors read and approved the final manuscript.

\section{Acknowledgements}

The present study was supported by NIA, AG 19899, U19 AG023122, AG31736, AG032290, The Ellison Medical Foundation, Southern Illinois University School of Medicine and Polish Ministry of Science and Higher Education (N N401 042638).

The authors would like to thank Dr. Robert G. Struble, PhD (Department of Neurology, Southern Illinois University School of Medicine, Springfield, IL, 
USA) for his support and advices and for allowing us to use the computerized microscopy analysis system. We also wish to thank Shari Beckman-Randall for technical assistance.

\section{Author details}

'Department of Oncological Endocrinology, Chair of Endocrinology and Metabolic Diseases, Medical University of Lodz, Lodz, Poland. 'Department of Internal Medicine, Geriatrics Research, Southern Illinois University School of Medicine, Springfield IL, USA. ${ }^{3}$ College of Medicine, Burnett School of Biomedical Sciences, University of Central Florida, Orlando, FL, USA. ${ }^{4}$ Institute of Human Genetics, Polish Academy of Sciences, Poznań, Poland.

${ }^{5}$ Department and Chair of Endocrinology and Metabolic Diseases, Medical University of Lodz, Lodz, Poland. ${ }^{6}$ Department of Endocrinology and Metabolic Diseases, Polish Mother's Memorial Hospital - Research Institute, Lodz, Poland.

Received: 18 July 2012 Accepted: 8 August 2012 Published: 16 August 2012

\section{References}

1. Lewiński A, Pawlikowski M, Cardinali DP: Thyroid growth-stimulating and growth-inhibiting factors. Biol Signals 1993, 2:313-351.

2. Fagman $\mathrm{H}$, Nilsson M: Morphogenesis of the thyroid gland. Mol Cell Endocrinol 2010, 323:35-54.

3. Brix K, Führer D, Biebermann H: Molecules important for thyroid hormone synthesis and action - known facts and future perspectives. Thyroid Res 2011, 4(Suppl 1):S9

4. De Felice M, Di Lauro R: Minireview: Intrinsic and extrinsic factors in thyroid gland development: an update. Endocrinology 2011, 152:2948-2956.

5. Iwata T, Yoshida T, Teranishi M, Murata Y, Hayashi $Y$, Kanou Y, Griffith AJ, Nakashima T: Influence of dietary iodine deficiency on the thyroid gland in Slc26a4-null mutant mice. Thyroid Res 2011, 4:10.

6. Gasperi M, Martino E, Manetti L, Arosio M, Porretti S, Faglia G, Mariotti S, Coalo AM, Lombardi G, Baldelli R, Camanni F, Liuzzi A, Acromegaly Study Group of the Italian Society of Endocrinology: Prevalence of thyroid diseases in patients with acromegaly: results of an Italian multi-center study. J Endocrinol Invest 2002, 25:240-245.

7. Gullu BE, Celik O, Gazioglu N, Kadioglu P: Thyroid cancer is the most common cancer associated with acromegaly. Pituitary 2010, 13:242-248.

8. Dos Santos MC, Nascimento GC, Nascimento AG, Carvalho VC, Lopes MH, Montenegro R Jr, Vilar L, Albano MF, Alves AR, Parente CV, Dos Santos Faria M: Thyroid cancer in patients with acromegaly: a case-control study. Pituitary 2012, in press, http://dx.doi.org/10.1007/s11102-012-0383-y.

9. Bartke $\mathrm{A}$ : Can growth hormone $(\mathrm{GH})$ accelerate aging ? Evidence from GH transgenic mice. Neuroendocrinology 2003, 78:210-216.

10. Sornson MW, Wu W, Dasen JS, Flynn SE, Norman DJ, O'Connell SM, Gukovsky I, Carriere C, Ryan AK, Miller AP, Zuo L, Gleiberman AS, Andersen B, Beamer WG, Rosenfeld MG: Pituitary lineage determination by the Prophet of Pit-1 homeodomain factor defective in Ames dwarfism. Nature 1996, 384:327-333.

11. Brown-Borg HM, Borg KE, Meliska CJ, Bartke A: Dwarf mice and the ageing process. Nature 1996, 384:33.

12. Bartke A, Coschigano K, Kopchick J, Chandrashekar V, Mattison J, Kinney B, Hauck S: Genes that prolong life: relationships of growth hormone and growth to aging and life span. J Gerontol A Biol Sci Med Sci 2001, 56:B340-B349.

13. Bartke A, Brown-Borg H: Life extension in the dwarf mouse. Curr Top Dev Biol 2004, 63:189-225.

14. Dominici FP, Hauck SJ, Argentino DP, Bartke A, Turyn D: Increased insulin sensitivity and upregulation of insulin receptor, insulin receptor substrate (IRS)-1 and IRS-2 in liver of Ames dwarf mice. J Endocrinol 2002, 173:81-94.

15. Hunter WS, Croson WB, Bartke A, Gentry MV, Meliska CJ: Low body temperature in long-lived Ames dwarf mice at rest and during stress. Physiol Behav 1999, 67:433-437.

16. Brown-Borg HM, Johnson WT, Rakoczy SG: Expression of oxidative phosphorylation components in mitochondria of long-living Ames dwarf mice. Age (Dordr) 2012, 34:43-57.

17. Zhou Y, Xu BC, Maheshwari HG, He L, Reed M, Lozykowski M, Okada S, Cataldo L, Coschigano K, Wagner TE, Baumann G, Kopchick JJ: A mammalian model for Laron syndrome produced by targeted disruption of the mouse growth hormone receptor/binding protein gene (the Laron mouse). Proc Natl Acad Sci USA 1997, 94:13215-13220.

18. Kopchick JJ, Laron Z: Is the Laron mouse an accurate model of Laron syndrome? Mol Genet Metab 1999, 68:232-236.

19. Coschigano KT, Clemmons D, Bellush LL, Kopchick JJ: Assessment of growth parameters and life span of GHR/BP gene disrupted mice. Endocrinology 2000, 141:2608-2613.

20. Bartke A, Chandrashekar V, Bailey B, Zaczek D, Turyn D: Consequences of growth hormone $(\mathrm{GH})$ overexpression and $\mathrm{GH}$ resistance. Neuropeptides 2002, 36:201-208.

21. Coschigano KT, Holland AN, Riders ME, List EO, Flyvbjerg A, Kopchick JJ: Deletion, but not antagonism, of the mouse growth hormone receptor results in severely decreased body weights, insulin, and insulin-like growth factor I levels and increased lifespan. Endocrinology 2003, 144:3799-3810.

22. Liu JL, Coschigano KT, Robertson K, Lipsett M, Guo Y, Kopchick JJ, Kumar U, Liu YL: Disruption of growth hormone receptor gene causes diminished pancreatic islet size and increased insulin sensitivity in mice. Am J Physiol Endocrinol Metab 2004, 287:E405-E413.

23. Salmon AB, Murakami S, Bartke A, Kopchick J, Yasumura K, Miller RA: Fibroblast cell lines from young adult mice of long-lived mutant strains are resistant to multiple forms of stress. Am J Physiol Endocrinol Metab 2005, 289:E23-E29.

24. Coschigano KT: Aging-related characteristics of growth hormone receptor/binding protein gene-disrupted mice. Age (Dordr) 2006, 28:191-200

25. Harper JM, Salmon AB, Chang Y, Bonkowski M, Bartke A, Miller RA: Stress resistance and aging: Influence of genes and nutrition. Mech Ageing Dev 2006, 127:687-694

26. Sun LY, Steinbaugh MJ, Masternak MM, Bartke A, Miller RA: Fibroblasts from long-lived mutant mice show diminished ERK1/2 phosphorylation but exaggerated induction of immediate early genes. Free Radic Biol Med 2009, 47:1753-1761.

27. Ikeno $Y$, Hubbard GB, Lee $S$, Cortez LA, Lew CM, Webb CR, Berryman DE, List EO, Kopchick JJ, Bartke A: Reduced incidence and delayed occurrence of fatal neoplastic diseases in growth hormone receptor/binding protein knockout mice. J Gerontol A Biol Sci Med Sci 2009, 64:522-529.

28. Gesing A, Bartke A, Wang F, Karbownik-Lewińska M, Masternak MM: Renal pro-apoptotic proteins are reduced by growth hormone resistance but not by visceral fat removal. Biol Chem 2011, 392:475-481.

29. Gesing A, Masternak MM, Wang F, Lewiński A, Karbownik-Lewińska M, Bartke A: Decreased expression level of apoptosis-related genes and/or proteins in skeletal muscles, but not in hearts, of growth hormone receptor knockout mice. Exp Biol Med 2011, 236:156-168.

30. Gesing A, Masternak MM, Wang F, Karbownik-Lewińska M, Bartke A: Deletion of growth hormone receptor gene but not visceral fat removal decreases expression of apoptosis-related genes in the kidney potential mechanism of lifespan extension. Age (Dordr) 2012, 34:295-304

31. Gesing A, Bartke A, Wang F, Karbownik-Lewińska M, Masternak MM: Key regulators of mitochondrial biogenesis are increased in kidneys of growth hormone receptor knockout (GHRKO) mice. Cell Biochem Funct 2011, 29:459-467.

32. Gesing A, Masternak MM, Wang F, Joseph A-M, Leeuwenburgh C, Westbrook R, Lewiński A, Karbownik-Lewińska M, Bartke A: Expression of key regulators of mitochondrial biogenesis in growth hormone receptor knockout (GHRKO) mice is enhanced but is not further improved by other potential life extending interventions. J Gerontol A Biol Sci Med Sci 2011, 66:1062-1076.

33. Hauck SJ, Hunter WS, Danilovich N, Kopchick JJ, Bartke A: Reduced levels of thyroid hormones, insulin, and glucose, and lower body core temperature in the growth hormone receptor/binding protein knockout mouse. Exp Biol Med 2001, 226:552-558.

34. Westbrook R, Bonkowski MS, Strader AD, Bartke A: Alterations in oxygen consumption, respiratory quotient, and heat production in long-lived GHRKO and Ames dwarf mice, and short-lived bGH transgenic mice. J Gerontol A Biol Sci Med Sci 2009, 64:443-451.

35. Suzuki S, Nishio S, Takeda T, Komatsu M: Gender-specific regulation of response to thyroid hormone in aging. Thyroid Res 2012, 5:1. 
36. Masternak MM, Wang F, Spong A, Gesing A, Bartke A: Effects of combined growth hormone deficiency and resistance in double-mutant Ames dwarf/GHR-KO mice [abstract]. Exp Gerontol 2011, 46:212-213.

37. Bartke A: Histology of the anterior hypophysis, thyroid and gonads of two types of dwarf mice. Anat Rec 1964, 149:225-235.

38. Li S, Crenshaw EB 3rd, Rawson EJ, Simmons DM, Swanson LW, Rosenfeld MG: Dwarf locus mutants lacking three pituitary cell types result from mutations in the POU-domain gene pit-1. Nature 1990, 347:528-533.

39. Cordier AC, Denef JF, Haumont SM: Thyroid gland in dwarf mice. Cell Tissue Res 1976, 171:449-457.

40. Brzeziński J, Lewiński A, Karbownik M, Gesing A, Modrzejewska H, Greger J: Effects of insulin-like growth factor I, epidermal growth factor and kalium iodide on thymidine kinase activity in homogenates of rat thyroid lobes incubated in vitro. Biomed Lett 1997, 55:153-167.

41. Lewiński A, Marcinkowska M, Brzeziańska E, Jeziorowska A, Włoch J, Brzeziński J: Expression of insulin-like growth factor I (IGF-I) gene and of genes for IGF-binding proteins 1, 2, 3, 4 (IGFBP-1-IGFBP-4) in nonneoplastic human thyroid cells and in certain human thyroid cancers. Effect of exogenous IGF-I on this expression. Endocr Res 2004, 30:47-59.

42. Kokoszko A, Karbownik M, Lewiński A: Increased lipid peroxidation in growth hormone-deficient adult patients. Neuroendocrinol Lett 2006, 27:225-230

43. Karbownik-Lewińska M, Kokoszko A, Lewandowski KC, Shalet SM, Lewiński A: $\mathrm{GH}$ replacement reduces increased lipid peroxidation in GH-deficient adults. Clin Endocrinol (Oxf) 2008, 68:957-964.

44. Kokoszko A, Dąbrowski J, Lewiński A, Karbownik-Lewińska M: Effects of growth hormone and insulin-like growth factor-I on the iron-induced lipid peroxidation in the rat liver and porcine thyroid homogenates. Neuroendocrinol Lett 2010, 31:517-523.

45. Kokoszko A, Dąbrowski J, Lewiński A, Karbownik-Lewińska M: Protective effects of GH and IGF-I against iron-induced lipid peroxidation in vivo. Exp Toxicol Pathol 2008, 60:453-458.

46. Karbownik M, Lewiński A: The role of oxidative stress in physiological and pathological processes in the thyroid gland; possible involvement in pineal-thyroid interactions. Neuroendocrinol Lett 2003, 24:293-303.

47. Smyczyńska J, Hilczer M, Stawerska R, Lewiński A: Thyroid function in children with growth hormone $(\mathrm{GH})$ deficiency during the initial phase of GH replacement therapy - clinical implications. Thyroid Res 2010, 3:2.

48. Smyczyńska J, Stawerska R, Lewiński A, Hilczer M: Do IGF-I concentrations better reflect growth hormone $(\mathrm{GH})$ action in children with short stature than the results of $\mathrm{GH}$ stimulating tests ? Evidence from the simultaneous assessment of thyroid function. Thyroid Res 2011, 4:6.

doi:10.1186/1756-6614-5-7

Cite this article as: Gesing et al:: Decreased thyroid follicle size in dwarf mice may suggest the role of growth hormone signaling in thyroid growth regulation. Thyroid Research 2012 5:7.

\section{Submit your next manuscript to BioMed Central and take full advantage of:}

- Convenient online submission

- Thorough peer review

- No space constraints or color figure charges

- Immediate publication on acceptance

- Inclusion in PubMed, CAS, Scopus and Google Scholar

- Research which is freely available for redistribution 